\title{
Ilex Paraguariensis as a Healthy Food Supplement for the Future World
}

\author{
Nelson Bracesco* \\ Dpto de Biofísica - Laboratorio de Radiobiología, Uruguay \\ *Corresponding author: Nelson Bracesco, Facultad de Medicina, Dpto de Biofísica- Laboratorio de Radiobiología. UdelaR, \\ Montevideo, Uruguay
}

\begin{tabular}{|c|c|}
\hline ARTICLE INFO & ABSTRACT \\
\hline 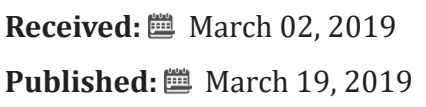 & $\begin{array}{l}\text { Citation: Nelson Bracesco. Ilex Paraguariensis as a Healthy Food Supplement for the Fu- } \\
\text { ture World. Biomed J Sci \& Tech Res 16(1)-2019. BJSTR. MS.ID.002808. }\end{array}$ \\
\hline
\end{tabular}

\section{Mini Review}

Before the conquest of America by the Spaniards, the native peoples of South America (Guaranies) cultivated the habit of drinking "mate". After the conquest, this habit was adopted by the colonizers and the trade in mate (green gold) began [1]. Yerba mate (Ilex paraguariensis A. St-Hill) is naturally distributed in the subtropical forests of eastern Paraguay, northeastern Argentina, southern Brazil and Uruguay in areas of vegetation refuge and great specific richness [2,3]. Its dried leaves are used to prepare a traditional infusion ("mate"). The main use of the Ilex paraguariensis crop is the production of yerba mate for consumption, with Argentina being the main producer with $62 \%$, followed by Brazil (32\%) and Paraguay (4\%). Yerba mate (Ilex paraguariensis) is exported to more than 60 countries distributed around the world, which implies the production of millions of tons ready for consumption. (Source: National (Argentinian) Institute of Yerba Mate, Brazilian Instute of Yerba Mate, Paraguayan center of Yerba Mate, 2017). Uruguay is the largest consumer of yerba mate per capita, where $85 \%$ of the population between 25 and 64 years old consumes yerba mate infusion at least once a week. (Source: OPS - MSP, STEP 2007). These data accomplish a great responsibility in the generation of knowledge with scientific support about properties of "Yerba Mate".

The improvement in product quality has been accompanied by studies carried on properties and effects on human health. This process in the region has been established among the Consumer, the Industry as well as the Academy. www.msp.gub.uy/sites/ default/.../2da\%20Encuesta\%20Factores\%20de\%20Riesgo.pdf. Recently, several reports have emerged showing the composition of the yerba mate leaf Ilex paraguariensis using different extraction methods $[3,4]$. Ilex paraguariensis extracts have found compounds with biological activity such as purine alkaloids (methylxanthines), flavonoids, tannins, chlorogenic acid and its derivatives and numerous triterpene saponins derived from ursolic acid [4-6]. Besides, methyl xanthines (caffeine and theobromine) are found in greater percentage. The presence of antioxidants such as polyphenols, which are found in high concentration, gives a very special feature to the infusion. Gugliucci [7], have published that the composition of antioxidants in the infusion of yerba is equivalent to that found in red wine and superior to that observed in green tea. In recent years, research works done on the effects of yerba mate on the human health claims that yerba mate is hypocholesterolemic, hepatoprotective [8-10], central nervous system stimulants, diuretics and antioxidant $[9,11]$. Benefits have also been shown for the cardiovascular system [12-14] and it is presented as a protector of DNA oxidation in vitro and low density lipoprotein (LDL) [15]. Even though there are some studies suggesting its potential in the treatment of obesity [16]. More recently, we have observed that yerba mate infusion intervene in the waking cycle to sleep, decreasing sleep and increasing attention.

Besides, we have recently published the radioprotective effect of yerba mate against the damage produced by ionizing radiation, explaining this effect by modulating the transduction cascades that act on the control genes at the cellular level and not exclusively by action of antioxidant compounds. In 1990, the International Agency for Research on Cancer office of the WHO (IARC) classified the infusion of yerba mate as a possible carcinogen based on a 
series of publications that linked consumption with different types of cancer, mainly the oropharynx $[17,18]$. Since then, research has been carried out to demonstrated a link between the consumption of hot beverages and cancer, as well as an antimutagenic and protective effect of the yerba mate infusion [19-21]. On the other hand, there are some authors who claimed that polycyclic aromatic hydrocarbons (PAH) derived from the incomplete combustion of wood as contaminants present in the yerba mate leaf, are responsible for the association between the infusion and cancer, because of the presence of PAH as they are recognized carcinogenic agents [22]. However, further Subsequent investigations documented the non-transmission of $\mathrm{PAH}$ to the infusion and also a protective effect of the infusion against the damage produced by certain PAHs [23]. In 2016, IARC committee of experts and proposes the reclassification of many foods, including yerba mate infusion. Based on the documented evidence, this group of experts suggested that IARCC classify the hot yerba mate infusion (greater than 65) as a carcinogenic potential based on consumption temperature and the Ilex paraguariensis leaf as a non-carcinogenic food [24].

\section{Conclusion}

In conclusion, we can say that there is accumulated scientific evidence, published in refereed scientific journals about the infusion of yerba mate consumed at temperatures below 65 degrees Celsius does not cause a problem to human health. What a great amount and quality of antioxidants that can contribute to our health, promoting endogenous defense systems capable of acting on the central nervous system and cardiovascular and DNA repair. Surely in the near future, the ilex paraguariensis is part of some pharmacological and food formulation.

\section{References}

1. Ricca J (2005) El Mate. Los secretos de la infusión. Desde la cultura nativa hasta nuestros días, ( $3^{\text {rd }}$ edn.), El Mendrugo, Montevideo, Uruguay.

2. Grela IA (2004) Geografía florística de las especies arbóreas de Uruguay: propuesta para la delimitación de dendrofloras. MSc Thesis, Universidad de la República, Montevideo, Uruguay, p. 97.

3. Giberti GC (2011) La "yerba mate" (Ilex paraguariensis, Aquifoliaceae) en tempranos escritos rioplatenses de Bonpland y su real distribución geográfica en Sudamérica austral. Bonplandia 20(2): 203-212.

4. Filip R, López P, Giberti G, Coussio J, Ferraro G (2001) Phenolic compounds in seven South American Ilex species. Fitoterapia 72(7): 774-778.

5. Heck CI, de Mejia EG (2007) Yerba mate tea (Ilex paraguariensis): a comprehensive review on chemistry, health implications, and technological considerations. J Food Sci 72(9): R138-R151.

6. Menini T, Heck C, Schulze J, de Mejia E, Gugliucci A (2007) Protective action of Ilex paraguariensis extract against free radical inactivation of paraoxonase-1 in high-density lipoprotein. Planta Med 73(11): 11411147

7. Markowicz D, Moura D, Lobato R, De Oliveira P, Lima M (2007) Yerba mate: pharmacological properties, research and biotechnology. Med Aromat Plant Sci. Biotechnol 1: 37-46.

8. Gugliucci A, Bastos DH (2009) Chlorogenic acid protects paraoxonase 1 activity in high density lipoprotein from inactivation caused by physiological concentrations of hypochlorite. Fitoterapia 80(2): 138142 .

9. Gugliucci A, Stahl AJC (1995) Low density lipoprotein oxidation is inhibited by extracts of Ilex paraguariensis. Biochem Mol Biol Int 35(1): 47-56.

10. Filip R, Ferraro GE (2003) Researching on new species of "Mate": Ilex brevicuspis: phytochemical and pharmacology study. Eur J Nutr 42(1): 50-54.

11. Messina D, Soto C, Méndez A, Corte C, Kemnitz M, et al. (2015) Lipid lowering effect of mate tea intake in dyslipidemic subjects. Nutr Hosp 31(5): 2131-2139.

12. VanderJagt TJ, Ghattas R, VanderJagt DJ, Crossey M, Glew RH (2002) Comparison of the total antioxidant content of 30 widely used medicinal plants of New Mexico. Life Sci 70(9): 1035-1040.

13. González Arbeláez LF, Fantinelli JC, Ciocci Pardo A, Caldiz CI, Ríos JL, et al. (2016) Effect of an Ilex paraguariensis (yerba mate) extract on infarct size in isolated rat hearts: the mechanisms involved. Food Funct $7(2)$ : 816-824.

14. Schinella G, Fantinelli JC, Mosca SM (2005) Cardioprotective effects of Ilex paraguariensis extract: evidence for a nitric oxide-dependent mechanism. Clin Nutr 24(3): 360-366.

15. Cuesta A, Guigou C, Varela A, Ferrero L, Charlin MC, et al. (2018) Acute effect of yerba mate (Ilex paraguariensis) consumption on heart rhythm in patients referred for Holter study. Arch Cardiol Mex 88(5): 468-473.

16. Bracesco N, Dell M, Rocha A, Behtash S, Menini T, et al. (2003) Antioxidant activity of a botanical extract preparation of Ilex paraguariensis: prevention of DNA double-strand breaks in Saccharomyces cerevisiae and human low-density lipoprotein oxidation. J Altern Complement Med 9(3): 379-387.

17. Andersen T, Fogh J (2001) Weight loss and delayed gastric emptying following a South American herbal preparation in overweight patients. J Hum Nutr Diet 14(3): 243-250.

18. Lubin JH, De Stefani E, Abnet CC, Acosta G, Boffetta P, et al. (2014) Maté drinking and esophageal squamous cell carcinoma in South America: pooled results from two large multicenter case-control studies. Cancer Epidemiol Biomarkers Prev 23(1): 107-116.

19. Kamangar F, Schantz MM, Abnet CC, Fagundes RB, Dawsey SM (2008) High levels of carcinogenic polycyclic aromatic hydrocarbons in mate drinks. Cancer Epidemiol Biomarkers Prev 17(5): 1262-1268.

20. Candreva EC, Keszenman DJ, Barrios E, Gelós U, Nunes E (1993) Mutagenicity induced by hyperthermia, hot mate infusion, and hot caffeine in Saccharomyces cerevisiae. Cancer Res 53(23): 5750-5753.

21. Ronco AL, De Stefani E, Lasalvia Galante E, Mendoza B, Vazquez A, et al. (2017) Hot infusions and risk of colorectal cancer in Uruguay: a casecontrol study. Eur J Clin Nutr pp. 130.

22. Bracesco N, Sánchez AG, Contreras V, Menini T, Gugliucci A (2011) Recent advances on Ilex paraguariensis research: minireview. J Ethno pharmacol 136(3): 378-384.

23. Bracesco N, Sosa V, Blanc L, Contreras V, Candreva EC, et al. (2018) Analysis of radioprotection and antimutagenic effects of Ilex paraguariensis infusion and its component rutin. Braz J Med Biol Res 51(9): e7404.

24. (2015) Thea, Ana \& Ferreira, Darío, Brumovsky, Luis \& Eduardo Schmalko, Miguel. Polycyclic Aromatic Hydrocarbons (PAHs) in yerba maté (Ilex paraguariensis St. Hil) traditional infusions (mate and tereré). Food Control, p. 60.

25. Dana Loomis, Kathryn Z Guyton, Yann Grosse, Béatrice Lauby Secretan, Fatiha El Ghissassi, et al. (2016) Carcinogenicity of drinking coffee, mate, and very hot beverages. International Agency for Research on Cancer Monograph Working Group. The Lancet Oncology 17(7): 877-878. 


\section{ISSN: 2574-1241}

DOI: 10.26717/BJSTR.2019.16.002808

Nelson Bracesco. Biomed J Sci \& Tech Res

(C) (P) This work is licensed under Creative

Submission Link: https://biomedres.us/submit-manuscript.php

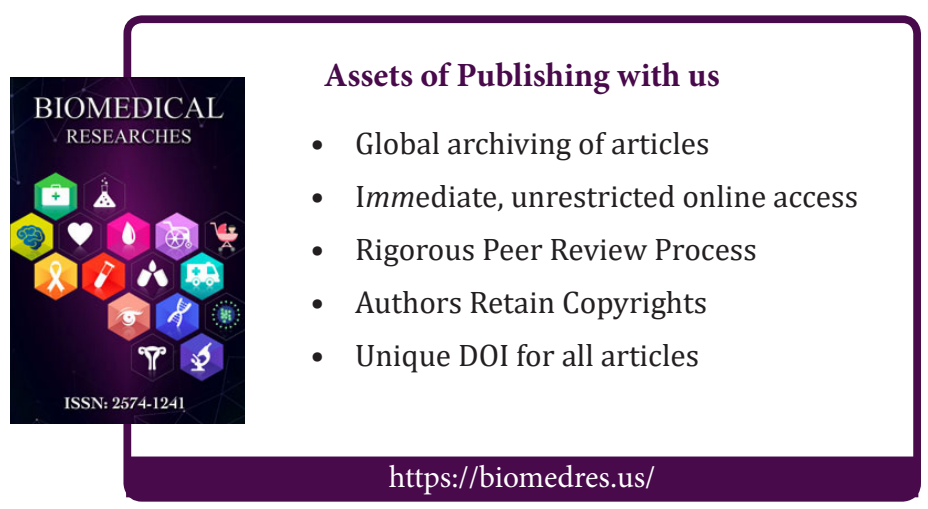

